\title{
A montelukasztterápia betegterheinek változása a generikus árverseny hatására
}

\author{
Répásy Balázs dr. ${ }^{1}$ - Endrei Dóra dr. ${ }^{1,2}$ - Zemplényi Antal dr. ${ }^{1,2}$ \\ Ágoston István dr. ${ }^{1}$ - Boncz Imre dr. ${ }^{1}$
}

Pécsi Tudományegyetem, ${ }^{1}$ Egészségtudományi Kar, Egészségbiztosítási Intézet, ${ }^{2}$ Klinikai Központ, Pécs

Bevezetés és célkitüzés: Célunk a montelukaszt hatóanyagú készítmények betegeket terhelő terápiás költségének vizsgálata volt Magyarországon.

Módszer: Vizsgálatainkat az Országos Egészségbiztosítási Pénztár gyógyszerforgalmi adatbázisára alapoztuk. A 2007 és 2015 közötti időszakra elemeztük a montelukaszt hatóanyagú gyógyszerek forgalmát és árát. Az alábbi indikátorokat használtuk: fogyasztói ár, napi terápiás költség, beteg általi térítési díj, kvázi térítési díj, a kezelési napok száma. Eredmények: A betegek által befizetett térítési díjtömeg a kezelési napok számának növekedése miatt 2011-ig nőtt, elérte a 277 millió forintot, majd 2012-ben a versenyhelyzet és a vaklicites eljárások miatt 133 millió forintra csökkent. A térítési díjtömeg az originális Singulairról 3 év alatt (2011-2014) áthelyeződött a generikumokra. A vizsgált időszakban a Singulair $10 \mathrm{mg}$ filmtabletta napi terápiás költsége 314 forintról 96 forintra, a Montelukast Teva $10 \mathrm{mg}$ filmtabletta napi terápiás költsége 187 forintról 46 forintra csökkent.

Következtetés: A generikus verseny hatására javult a montelukasztterápia hozzáférhetősége: nőtt a kezelési napok száma, és csökkent a betegek által fizetendő térítési díj.

Orv Hetil. 2018; 159(17): 682-687.

Kulcsszavak: térítési díj, árverseny, vaklicit, gyógyszerpiac, montelukaszt

\section{The patients' cost of the montelukast therapy due to the generic substitution}

Introduction and aim: The aim of our study was to analyse the public price of the montelukast sodium therapy in Hungary.

Method: Data derived from the nationwide pharmaceutical database of the Hungarian National Health Insurance Fund Administration. We observed the turnover and price of the medicaments containing the active substance montelukast sodium from 2007 to 2015. Accordingly, our indicators were: consumer price, DCT (daily cost of therapy), co-payment, quasi co-payment, DOT (days of treatment).

Results: Due to the increasing DOT, the total amount of the public price paid by the patients increased until 2011, reaching the amount of 1 million USD; then, due to the generic competition and the blind bid methods, it decreased to 490000 USD. The total amount of the public price of the brand-name Singulair moved to the generics during 3 years (2011-2014). The DCT of the originator Singulair $10 \mathrm{mg}$ tablets decreased from 1.1 USD to 0.34 USD; the DCT of the generic product Montelukast TEVA decreased from 0.67 USD to 0.16 USD in the period under review. Conclusion: Due to the generic competition, the patients' access to drugs containing montelukast sodium increased significantly: the DOT increased, the co-payment decreased.

Keywords: public price, generic competition, blind bid, access, drug market, montelukast

Répásy B, Endrei D, Zemplényi A, Ágoston I, Boncz I. [The patients' cost of the montelukast therapy due to the generic substitution]. Orv Hetil. 2018; 159(17): 682-687.

(Beérkezett: 2017. december 10.; elfogadva: 2018. január 20.) 


\section{Rövidítések}

DCT $=($ daily cost of therapy $)$ napi terápiás költség; DDD = (defined daily dose) a WHO által meghatározott, az adott hatóanyagra vonatkozó napi dózis; DOT $=($ days of treatment $)$ a kezelési napok száma; NEAK = Nemzeti Egészségbiztosítási Alapkezelő; NTK = napi terápiás költség; OEP = Országos Egészségbiztosítási Pénztár; OGYI = Országos Gyógyszerészeti Intézet; WHO = (World Health Organization) Egészségügyi Világszervezet

Az originális gyógyszerkészítmények generikus készítményekkel történő helyettesítése felvet néhány kérdést a gyakorló orvos számára. A generikum felírása során figyelemmel kell lenni az orvosszakmai kérdésekre és a gazdasági kérdésekre egyaránt [1].

Az Országos Egészségbiztosítási Pénztár (OEP; ma: Nemzeti Egészségbiztosítási Alapkezelő, NEAK) által bevezetett vaklicites eljárások következtében sok gyógyszercsoportnál jelentős megtakarítás volt megfigyelhetô a kiáramló társadalombiztosítási támogatás összegében [2]. Kevésbé ismertek a lakosságot érintő kiadások. Az első montelukasztkészítmény, a Singulair - az MSD Pharma Hungary Kft. terméke - 1998. január elsején kapta meg Magyarországon a forgalomba hozatali engedélyt. A szabadalmi védettség lejárta után, 2011 októberétôl számos montelukasztgenerikum jelent meg a magyar gyógyszerpiacon, szinte egy időben a vaklicites eljárások bevezetésével [3]. A generikus verseny megindulása után jelentős árcsökkenés volt megfigyelhető a magyar gyógyszerpiacon $[4,5]$.

A generikumok az eredeti (originális) gyógyszerrel megegyező hatóanyagú és hatáserősségú, az Országos Gyógyszerészeti és Élelmezés-egészségügyi Intézet
(OGYÉI) által „helyettesíthetőnek” minősített gyógyszerek. A generikus gyógyszerek árába nem kell beépíteni a hatóanyag kifejlesztésének és a klinikai vizsgálatok költségének jelentős részét, emiatt jóval alacsonyabb áron is piacképesek.

Elemzésünk célja a generikus árverseny ('gyógyszerárcsökkentés') hatásának felmérése a betegek által fizetendő térítési díjakra a montelukaszt hatóanyag példáján.

\section{Adatok és módszer}

Vizsgálatainkat az OEP publikus gyógyszerforgalmi adatbázisára alapoztuk; 2007-től elemeztük a montelukaszt hatóanyagú originális készítmény, illetve generikus gyógyszerek forgalmát és árát. Az elemzésben szereplő adatok az Országos Egészségbiztosítási Pénztár gyógyszerforgalmi adatbázisából származnak, mely adatbázis a támogatott gyógyszertári gyógyszerforgalmat prezentálja. Retrospektív vizsgálatunkhoz havi bontásban gyújtöttük ki a szükséges gyógyszerforgalmi adatokat, majd ezeket aggregáltuk éves szinten.

A generikus verseny vizsgálatát az árverseny elemzésével kezdtük, megvizsgálva az originális Singulair és a legjelentősebb generikum bruttó térítési díjának alakulását 2008 és 2015 között (1.ábra). Folytatásként meghatároztuk a montelukasztkészítmények kezelési napokkal (days of treatment, DOT) számolt forgalmát (2. ábra). A gyógyszerek forgalmát az OEP-adatbázis DOT-ban adja meg, ez a terápiás napok száma. A DOT egyenesen arányos a gyógyszer kiszerelésével, hatáserősségével és dobozforgalmával, s fordítottan arányos a DDD-vel (defined daily dose), azaz a WHO által meghatározott, az adott hatóanyagra vonatkozó napi dózissal. A továbbiak-

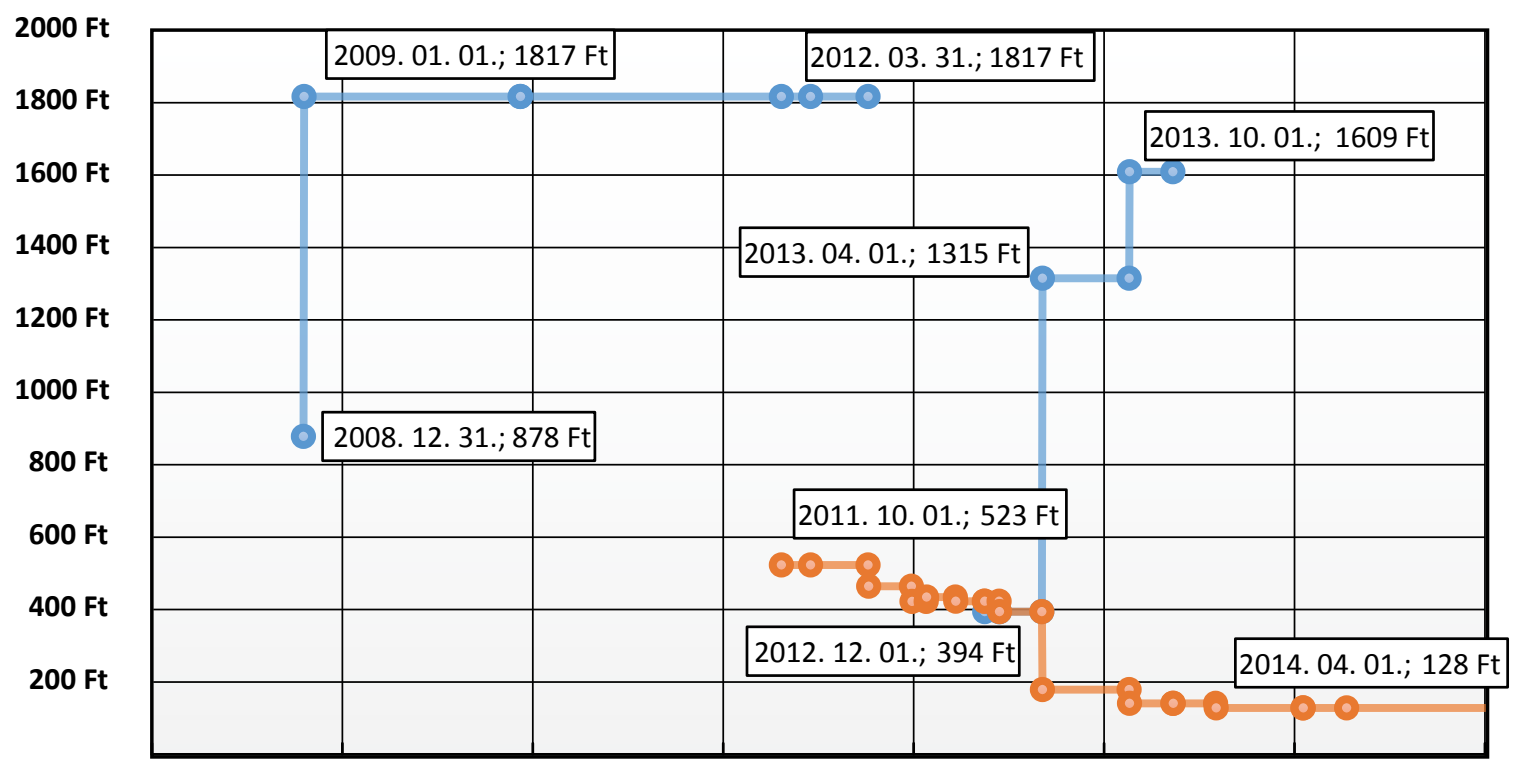

2008. 02. 16. 2009. 03. 22. 2010.04. 26. 2011.05.31. 2012.07.04. 2013.08.08. 2014. 09.12. 2015.10.17. - - Singulair

- Montelukast Teva

1. ábra | A Singulair $10 \mathrm{mg}$ filmtabletta és a Montelukast Teva $10 \mathrm{mg}$ filmtabletta térítési díja EüE jogcímen 2008-2015 

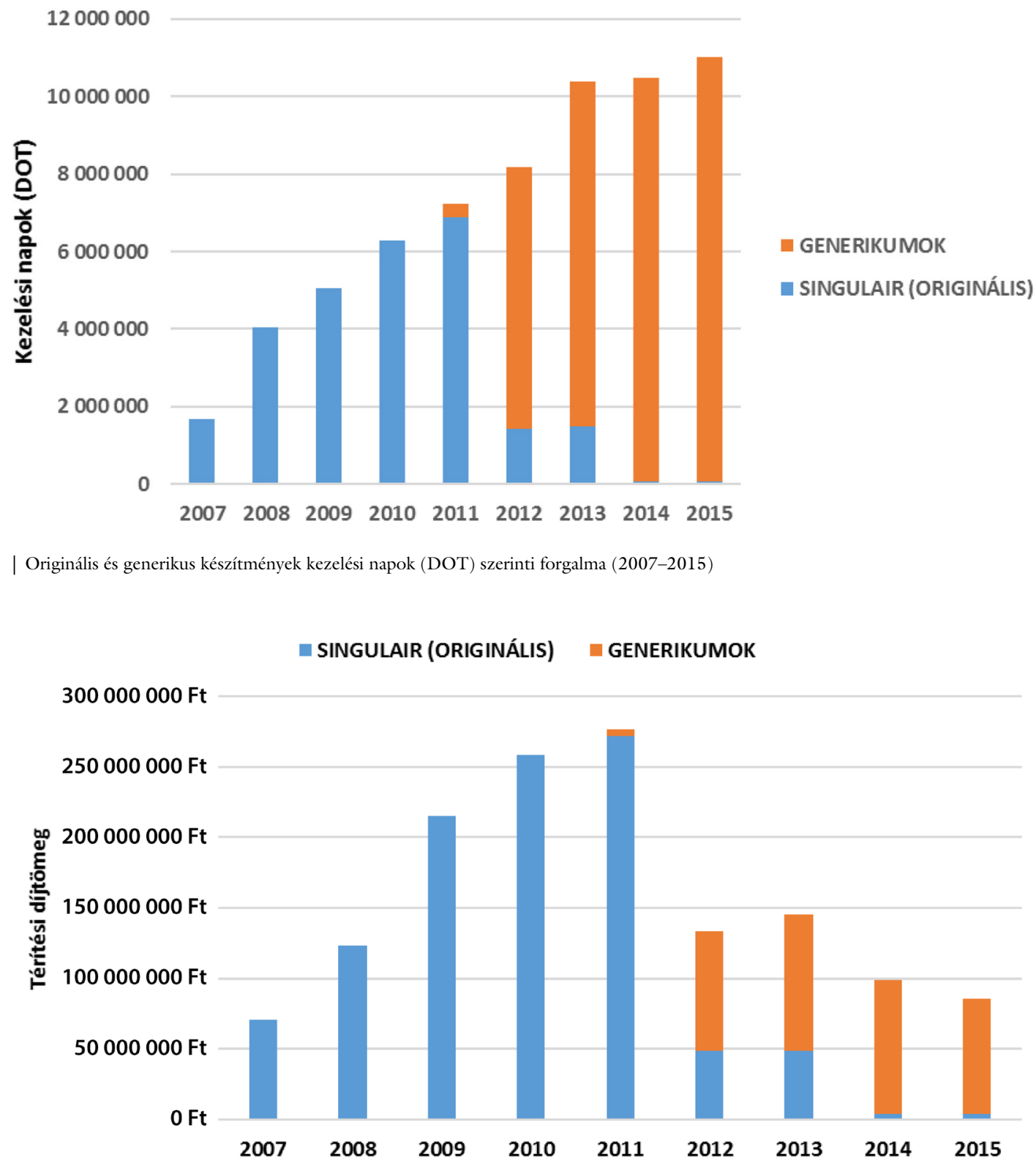

ban megvizsgáltuk a térítési díjtömeg mértékét és megoszlását az originális gyógyszer és a generikumok között (3. és 4. ábra). Végül kiszámítottuk a Montelukast Teva $10 \mathrm{mg}$ filmtabletta napi terápiás költségét (NTK), és ábrázoltuk az idő függvényében a Singulair $10 \mathrm{mg}$ filmtablettáéval összehasonlítva (5. ábra).

A kutatásban a következő indikátorokat alkalmaztuk: DOT, bruttó térítési díj (amit a beteg egy doboz gyógyszer után fizet), térítési díjtömeg (az összes beteg összes kiadása), NTK és társadalombiztosítási támogatás. Mivel az OEP-adatbázis csak a támogatott gyógyszerforgalmat tartalmazza, a teljes áras vagy a támogatás nélkül kiváltott készítmények forgalmára nem volt rálátásunk [6]. A magyar egészségügyi rendszer felépítésének [7-10] és finanszírozási jellemzőinek [11-15] részletesebb bemutatása máshol megtalálható.

\section{Eredmények}

Az 1. ábrán látható, hogy a Singulair $10 \mathrm{mg}$ filmtabletta gyógyszertárban fizetendő térítési díja 2009 januárjától jelentősen megnótt, 878 forint helyett 1817 forintot kellett fizetni egy doboz gyógyszerért. Az árnövekedést a társadalombiztosítási támogatás mérséklése okozta, a gyógyszer bruttó fogyasztói teljes ára maradt 8783 forint. A generikumok megjelenésére 2011 októberéig kellett várni, ekkor azonban jóval alacsonyabb áron nyújtottak alternatívát a montelukasztterápiában. A Montelukast Teva $10 \mathrm{mg}$ filmtabletta induló térítési díja 523 forint volt, ami a Singulair árának kevesebb, mint a harmada. Az OEP 2012 áprilisától ki is vonta a támogatott gyógyszerek köréból a Singulair $10 \mathrm{mg}$ filmtablettát. Az MSD Pharma Hungary Kft. nem szerette volna elveszteni piaci 
E SINGULAIR (ORIGINÁLIS) — GENERIKUMOK

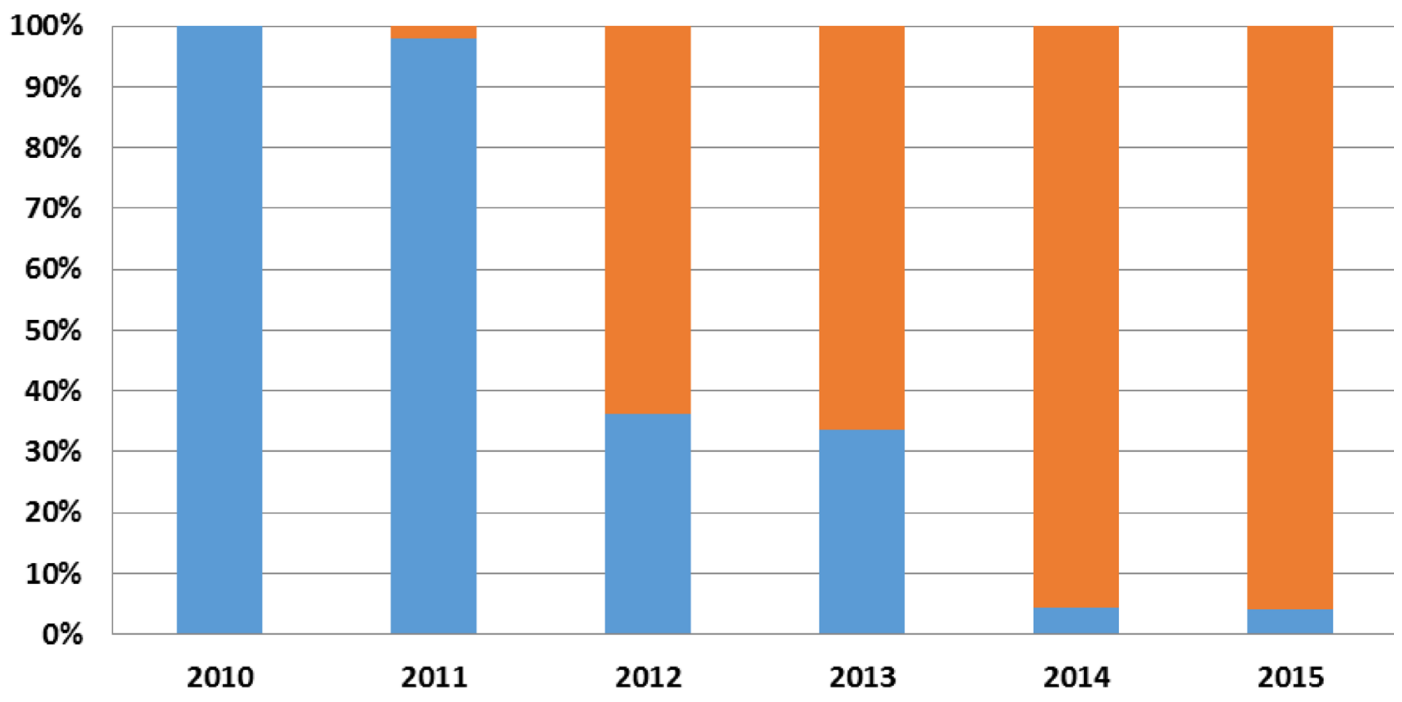

4. ábra | A térítési díjtömeg megoszlása a Singulair és a generikumok között (2010-2015)

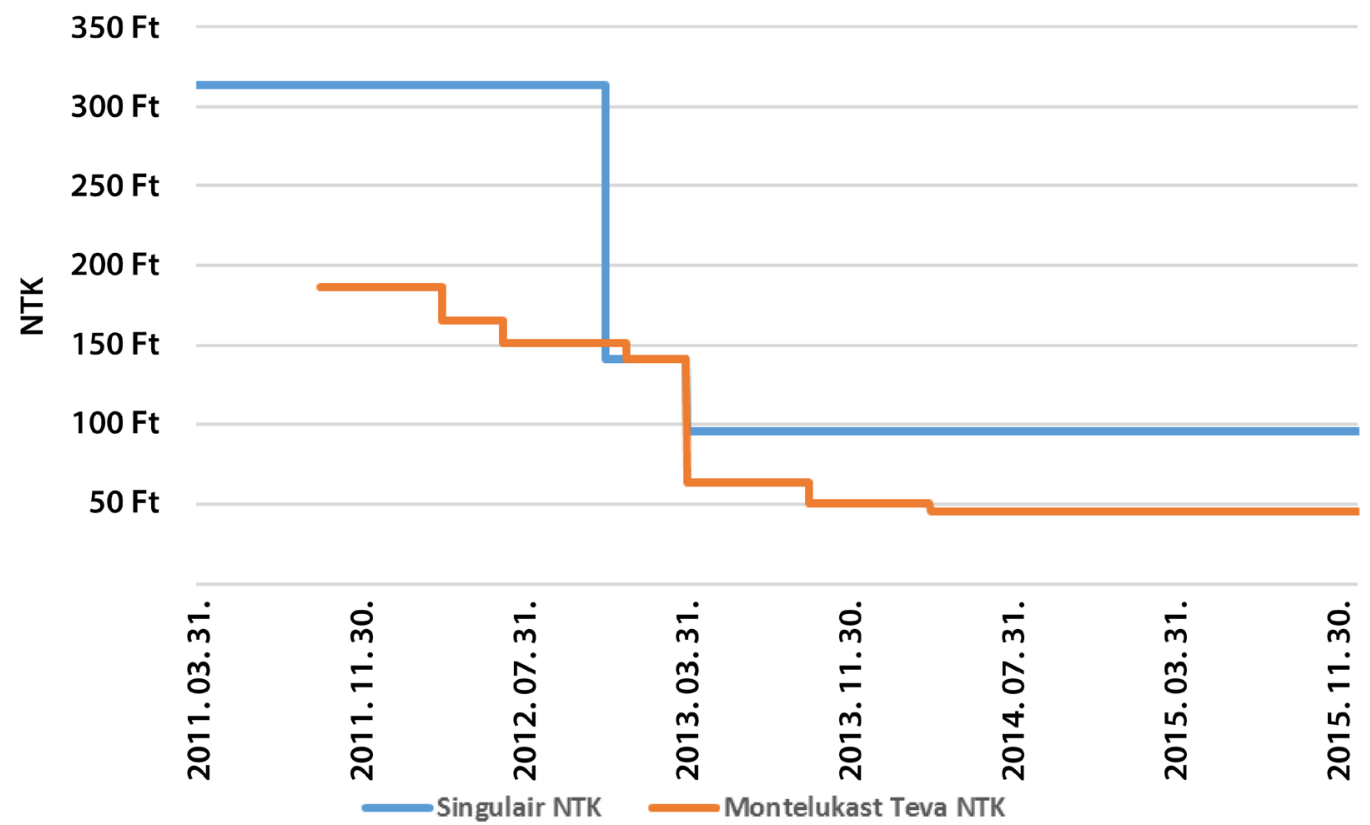

5. ábra

| A Singulair $10 \mathrm{mg}$ filmtabletta és a Montelukast Teva 10 mg filmtabletta napi terápiás költségének (NTK) alakulása az idő függvényében (2011-2015)

pozícióját, és jelentős árcsökkentést hajtott végre, 2012 decemberétól a Singulair $10 \mathrm{mg}$ filmtablettát ismét támogatásba vonta az OEP: 394 forintos térítési díjával sikerült sok generikum, így a Montelukast Teva 423 forintos ára alá menni. A 2013. évi áprilisi vaklicit során a bruttó fogyasztói árcsökkentésben a generikumok megelőzték, a támogatás mértéke jelentősen csökkent, így 1315 forintra nőtt a térítési díja. A Singulair $10 \mathrm{mg}$ filmtabletta 2014 óta nem támogatott Magyarországon.

A 2. ábrán a kezelési napok (DOT) szerinti forgalom alakulása látható. Az ábrán szétbontva ábrázoltuk az originális Singulair és a generikumok DOT-forgalmát, így látható, hogy növekvő piacon léptek be a generikumok a versenybe, és 2014-re áthelyeződött a forgalom a generikumokra.

A 3. ábrán a Singulair és a generikumok térítési díjtömege látható. Az itt jelzett adatok aggregáltak, függetlenek a hatáserősségtől, a kiszereléstől és a gyógyszerformától. A térítési díjtömeg 2011-ig együtt nőtt a DOT-forgalom növekedésével, 2012-től viszont a jelentős árcsökkenés túlszárnyalta a DOT-forgalom növekedését, és csökkent a kifizetett térítési díjtömeg. A 3. és 4. ábrán is látható, hogy a térítési díjtömeg áthelyeződött a generikumokra; a Singulair 2014-re szinte teljesen kiszo- 
rult a támogatott gyógyszerek piacáról, az originális MSD montelukasztpiaci részesedése $5 \%$ alá csökkent. A 4. ábrán ez 100\%-ig halmozott oszlopdiagramon látható.

A fogyasztói teljes árat 1 DOT-ra vonatkoztatva megkapjuk a gyógyszer napi terápiás költségét (NTK). Az 5. ábrán látható, hogy a Singulair $10 \mathrm{mg}$ filmtabletta és a Montelukast Teva $10 \mathrm{mg}$ filmtabletta napi terápiás költsége jelentősen csökkent a vizsgált időszakban. Míg 2011-ben 314 forint volt a Singulair napi terápiás költsége, a 2013-as áprilisi vakliciten 96 forintra csökkent. A Montelukast Teva $10 \mathrm{mg}$ filmtabletta induló napi terápiás költsége 187 forint volt 2011 októberében, 2013 áprilisára 64 Ft-ra csökkent.

\section{Megbeszélés}

Vizsgálatunkban arra kerestük a választ, hogy az OEP költségcsökkentő eljárásai milyen hatással vannak a lakossági térítési díjakra. Vizsgálatunk alapját egy, az asztma kezelésében használt, orálisan szedhető hatóanyag, a montelukaszt (montelukaszt-nátrium) képezte.

A generikumok az originális gyógyszerrel megegyező hatóanyagú és hatáserősségü készítmények, melyek egyenértékűségét a törzskönyvezési eljárás során igazolják. Ugyanakkor igen gyakran felvetődik mind orvosszakmai, mind finanszírozói oldalról a helyettesíthetőség kérdése. Általában a finanszírozó szervezetek preferálják az olcsóbb generikus készítményeket, míg az orvosok és a betegek körében az áron felül más szempontok is felvetődnek $[16,17]$. A patikai forgalomban az előző szempontok mellett más kérdések, így például az árrés kérdése is előkerülhet. Mindazonáltal a generikumok jóval alacsonyabb áron kerülnek forgalomba, ezáltal növekedhet a betegek gyógyszerhozzáférése, ami azt jelenti, hogy a betegek szélesebb köre férhet hozzá a készítményekhez: 2010 és 2015 között 6,3 millióról 11 millióra nőtt a kezelési napok száma (DOT), ami 75\%-os növekedést jelent.

A nagy értékü (például: ritka betegségek kezelésére szánt, innovatív) gyógyszerek hozzáférhetőségének kérdése Magyarországon társadalmi probléma a szúkös források miatt [18]. A generikumok megjelenésével létrejön a piaci verseny, és jelentősen csökken az originális gyógyszerek ára is, ehhez azonban meg kell várni a szabadalmi védettség lejártát. Az ekkor megfigyelhetó árcsökkenést fokozza a piacon lévő versenytársak száma [19-22]. A generikus versenyt sok országban, így Magyarországon is állami intézkedésekkel (ármaximalizálás, referenciaárhoz kötött támogatás) fokozzák, ám ezek hosszú távú előnyeit bizonyos szakirodalmak vitatják [ 1 , 23, 24]. Az Országos Egészségbiztosítási Pénztár (OEP) fixesítési eljárásaiban a konkurens forgalmazók nem látják egymás ajánlatait, a referenciakészítmény és valamennyi, a fix csoportba került készítmény támogatása utólag kerül közlésre. Ezzel a módszerrel fokozható az árcsökkenés mértéke. Érdekesség, hogy az első 'vaklicit' éppen 2011 októberében volt, akkor, amikor a montelukasztgenerikumok piacra léptek. Esetünkben a generikus verseny és az OEP költségcsökkentő eljárásainak köszönhetően a növekvő DOT-forgalom ellenére is csökkentek a betegek összesített terhei. Egy dobozra nézve az originális Singulair $10 \mathrm{mg}$ filmtabletta térítési díja a generikumok megjelenése előtt 1817 Ft volt, másfél évvel később viszont már csak 179 forintot kellett fizetni a gyógyszertárban egy doboz generikus gyógyszerért.

\section{Következtetés}

Az árcsökkenés és a piaci verseny által generált forgalomnövekedés a csökkenő árak ellenére is a társadalombiztosítási támogatás fokozódó kiáramlásához vezethet [25]. A montelukasztpiacon azonban csökkent a kiáramló társadalombiztosítási támogatás is [2]. Az így fennmaradó támogatási összeg reményeink szerint új gyógyszerek támogatásba történő befogadására lesz fordítható.

Anyagi támogatás: A kutatás az „EFOP-3.6.2-16-201700009 Klinikai Kutatások Tematikus Hálózatának Kialakítása és Nemzetköziesítése" pályázat támogatásával készült.

Szerzôi munkamegosztás: R. B.: A hipotézis kidolgozása, szakirodalom-keresés, az adatok elemzése, a kézirat megszövegezése. E. D., Á. I.: A hipotézis kidolgozása, a kézirat megszövegezése. Z. A., B. I.: A hipotézis kidolgozása, az adatok elemzése, a kézirat megszövegezése. A cikk végleges változatát valamennyi szerző elolvasta és jóváhagyta.

Érdekeltségek: A szerzőknek nincsenek érdekeltségeik.

\section{Irodalom}

[1] Kerpel-Fronius S. Medical problems associated with the national reference pricing system in Hungary. [A hazai referencia gyógyszerárképzés orvosszakmai problémái.] Orv Hetil. 2004; 145 : 913-918. [Hungarian]

[2] Communication from the National Health Insurance Fund Administration: Results in figures (2013-07-10). [Az Országos Egészségbiztosítási Pénztár közleménye: Az OEP eredményei számokban (2013. 07. 10.)] Available from: http://www.oep. hu/data/cms982468/AZ_OEP_EREDMENYEI_SZAMOKBAN.PDF?query=vaklicit [accessed: December 21, 2016]. [Hungarian]

[3] ESzCsM Regulation No. 32/2004 (IV. 26.) on the criteria of registered medicinal products and formula meeting special nutritional needs to be covered by social security and the change of the admission or the social security support. [32/2004. (IV. 26.) ESzCsM rendelet a törzskönyvezett gyógyszerek és a különleges táplálkozási igényt kielégító tápszerek társadalombiztosítási támogatásba való befogadásának szempontjairól és a befogadás vagy a támogatás megváltoztatásáról.] [Hungarian]

[4] Répásy B, Endrei D, Boncz I, et al. The effect of generic price competition on drug consumption and health insurance pharmaceutical expenditures in Hungary. [Generikus árverseny hatása a gyógyszerforgalomra és a társadalombiztosítási támogatás 
kiáramlásra Magyarországon.] Acta Pharm Hung. 2015; 85: 83-88. [Hungarian]

[5] Hornyák L, Nagy Zs, Tálos Zs, et al. Experiences with price competition of biosimilar drugs in Hungary. [A biohasonló gyógyszerek árversenyének tapasztalatai Magyarországon.] Acta Pharm Hung. 2014; 84: 83-87. [Hungarian]

[6] Gresz M. Evaluating the National Health Insurance database of Hungary from the aspect of a health insurance specialist. [Az Országos Egészségbiztosítási Pénztár adatbázisa az egészségbiztosítási szakorvos szemével.] Orv Hetil. 2012; 153: 1234-1239. [Hungarian]

[7] Gaal P, Szigeti S, Csere M, et al. Hungary. Health system review. Health Syst Transit. 2011; 13: 1-266.

[8] Kaló Z, Bodrogi J, Boncz I, et al. Capacity building for HTA implementation in middle-income countries: The case of Hungary. Value Health Regional. 2013; 2: 264-266.

[9] Gulacsi L, Boncz I, Drummond M. Issues for countries considering introducing the "fourth hurdle": The case of Hungary. Int J Technol Assess Health Care 2004; 20: 337-341.

[10] Endrei D, Zemplényi A, Molics B, et al. The effect of performance-volume limit on the DRG based acute care hospital financing in Hungary. Health Policy 2014; 115: 152-156.

[11] Boncz I, Nagy J, Sebestyen A, et al. Financing of health care services in Hungary. Eur J Health Econ. 2004; 5: 252-258.

[12] Boncz I, Dozsa C, Kalo Z, et al. Development of health economics in Hungary between 1990-2006. Eur J Health Econ. 2006; 7(SI): 4-6.

[13] Endrei D, Molics B, Ágoston I. Multicriteria decision analysis in the reimbursement of new medical technologies: real-world experiences from Hungary. Value Health 2014; 17: 487-489.

[14] Boncz I, Sebestyen A. Financial deficits in the health services of the UK and Hungary. Lancet 2006; 368: 917-918.

[15] Boncz I, Evetovits T, Dózsa Cs, et al. The Hungarian Care Managing Organization pilot program. Value Health Regional. 2015; 7: 27-33

[16] Remport Á, Dankó D, Gerlei Z, et al. Special considerations in generic substitution of immunosuppressive drugs in transplantation. [Követőkészítmények alkalmazásának lehetőségei a transzplantáció immunszuppresszív terápiájában.] Orv Hetil. 2012; 153: 1341-1349. [Hungarian]
[17] Szapáry L, Fehér G. Effectiveness of generic rosuvastatin in pa tients with ischaemic cerebrovascular disease. [A generikus rosuvastatin hatékonyságának vizsgálata cerebrovascularis betegekben.] Orv Hetil. 2012; 153: 857-860. [Hungarian]

[18] Szegedi M, Molnár MJ, Boncz I, et al. Focus shifts in the Hun garian reimbursement system. Funding of orphan medicinal products for rare disease patients in Hungary: Financing of orphan medicines. [Hangsúlyeltolódások a hazai gyógyszerek finanszírozásában. A ritka betegségek kezelésére szolgáló árva gyógyszerek támogatása. Enzimpótló kezelések finanszírozása hazánkban.] Orv. Hetil. 2014; 155: 1735-1741. [Hungarian]

[19] U.S. Food and Drug Administration. Generic Competition and Drug Prices. Secondary Generic Competition and Drug Prices, 2015. Available from: http://www.fda.gov/AboutFDA/CentersOffices/OfficeofMedicalProductsandTobacco/CDER/ ucml29385.htm [accessed: October 21, 2015].

[20] Spinks J, Chen G, Donovan L. Does generic entry lower the prices paid for pharmaceuticals in Australia? A comparison before and after the introduction of the mandatory price-reduction policy. Aust Health Rev. 2013; 37: 675-681.

[21] Dylst P, Simoens S. Does the market share of generic medicines influence the price level? Pharmacoeconomics 2011; 29: 875882.

[22] Aalto-Setälä V. The impact of generic substitution on price competition in Finland. Eur J Health Econ. 2008; 9: 185-191.

[23] Puig-Junoy J. Impact of European pharmaceutical price regulation on generic price competition: a review. Pharmacoeconomics 2010; 28: 649-663.

[24] Simoens S. A review of generic medicine pricing in Europe. GaBI Journal 2012; 1: 8-12.

[25] Herczeg B, Katona K, Kaló Z. Hungarian paradox: Generic medicines increase health spending. [Magyar paradoxon: a generikus gyógyszerek növelik az egészségügyi kiadásokat.] IME 2007; 6: 21-24. [Hungarian]

(Répásy Balázs dr., Pécs, Mária u. 5-7., 7621 e-mail: theophyllinum@gmail.com)

\section{Tisztelt Szerzőink, Olvasóink!}

Az Orvosi Hetilapban megjelenő/megjelent közlemények elérhetőségére több lehetőség kínálkozik.

Rendelhetö különlenyomat, melynek áráról bővebben a www.akkrt.hu honlapon (Folyóirat Szerzőknek, Különlenyomat menüpont alatt) vagy Szerkesztöségünkben tájékozódhatnak.

A közlemények megvásárolhatók pdf-formátumban is, illetve igényelhető Optional Open Article (www.oopenart.com).

Adott dij ellenében az online közlemények bárki számára hozzáférhetök honlapunkon (a közlemények külön linket kapnak, így más oldalról is linkelhetővé válnak).

Bővebb információ a hirdetes@akkrt.hu címen vagy különlenyomat rendelése esetén a Szerkesztőségtől kérhető. 